UDC 656.611:258.155

JEL C60 M11

DOI 10.31375/2226-1915-2019-4-15-25

O.D. Vyshnevska

$\mathrm{PhD}$, docent of the Department of Fleet Operations and Shipping Technologies ORCID ID 0000-0003-1021-3176vishn.ol.24@ukr.net

D. O. Vyshnevskyi

$\mathrm{PhD}$, docent of the Department of Fleet Operations and Shipping Technologies ORCID ID 0000-0002-1270-713Xvishn.do@gmail.com

S.P. Onyshchenko

DSc (Econ.), Professor of the Department of Fleet Operations and Shipping Technologies ORCID ID 0000-0002-9660-1921onyshenko@gmail.com

Odessa National Maritime University, Odessa, Ukraine

\title{
MODELING OF THE DISTRIBUTION OF THE VESSELS' TIME BUDGET UNDER LONG-TERM FREIGHT CONTRACTS WITHIN CONDITIONS OF UNCERTAINTY
}

Abstract. A model for allocation of vessels' time budget under long-term freight contracts in the conditions of fuzzy uncertainty is developed, taking into account the fact that in a "free» from work time under these contracts, vessels can operate in an open freight market. Fuzzy uncertainty is manifested in the fact that the parameters of the transport process, technical and operational indicators of vessels' performance and the volumes of transport work are presented in the form of maximum, minimum and most expected, which corresponds to the actual situation in the shipping management.

The proposed model allows to define: the number of vessels of a certain type, which should be taken in time charter lease to achieve specific goals and conditions; the allocation of the company's own vessels and leased vessels under long-term contracts and, accordingly, the selection of contracts (as a result of optimization, individual contracts may be identified as not effective for the company; determination of the time budget shares of vessels (own and leased), within which they will carry out transportation under these contracts, as well as time budget shares, within which they will work on the free freight market. At the same time, established values of the variables ensure the maximization of operating profit, with the consideration of it's minimum permissible boundary.

Technical and operational performance of the vessels and the characteristics of contracts and indicators characterizing the situation on the freight market are presented in the form of fuzzy numbers of a triangular type, which reflects the practical availability of information (minimum, maximum, and most possible).

The results obtained from the model take into account the uncertainty of the conditions formulated in the form of fuzzy numbers, describing the values of technical and operational indicators, as well as the characteristics of long-term contracts and the situations on the freight market. Practical use of the model allows shipowners to plan the work of vessels and evaluate the results of their work in the absence of complete information, based on analysts' forecasts, presented in the form of fuzzy numbers.

Keywords: shipping, fuzzy sets, optimization, fleet operating, contracts of affreightment.

( Вишневська О.Д., Вишневський Д.О., Онищенко С.П., 2019 
У ДК 656.611:258.155

\section{JEL C60 M11}

DOI 10.31375/2226-1915-2019-4-15-25

О.Д. Вишневська

к.т.н., доцент кафедри «Експлуатація флоту і технології морських перевезень» vishn.ol.24@ukr.net Д.О. Вишневський

к.т.н., доцент кафедри «Експлуатація флоту і технології морських перевезень» vishn.do@gmail.com

С.П. Онищенко

д.е.н., проф., професор кафедри «Експлуатація флоту і технології морських перевезень» onyshenko@gmail.com

Одеський національний морський університет, Украӥна

\section{МОДЕЛЮВАННЯ РОЗПОДІЛУ \\ БЮДЖЕТУ ЧАСУ СУДЕН \\ ПО ДОВГОСТРОКОВИМ ФРАХТОВИМ КОНТРАКТАМ}

В УМОВАХ НЕВИЗН АЧЕНОСТІ

Анотація. Розроблено модель розподілу бюджету часу суден за довгостроковими контрактами в умовах нечіткої невизначеності урахуванням того факту, щчо в «вільний» від роботи час за иими контрактами судна можуть працювати на відкритому фрахтовому ринку. Нечітка невизначеність проявлясться в тому, шо параметри транс-портного процесу, технічні та експлуатаиійні показники роботи суден $і$ обсяги транспортної роботи представлені у вигляді максимального, мінімального і найбільи очікуваного значень, що відповідає реальній ситуачії в судноплавстві. Запропонована модель дозволяе визначити: кількість суден певного типу, яке необхідно взяти в тайм-чартерну оренду для досягнення конкретних иілей при заданих умовах; розподіл власних та орендованих суден компанії за довгостроковими контрактами $i$, відповідно, вибір контрактів (в результаті оптимізації окремі контракти можуть бути визначені як неефективні); визначення термінів $і$ бюджету часу суден (власних та орендованих), в рамках яких вони здійснюватимуть перевезення за ичими контрактами, а також частки бюджету часу, в межах яких вони будуть праиювати на фрахтовому ринку. Встановлені значення змінних забезпечують максимізачію операчійного прибутку, з урахуванням iï мінімально допустимої межі. Практичне використання моделі дозволяє судновласникам планувати роботу суден і оиінювати результати їх роботи при відсутності повної інформації, заснованої на прогнозах аналітиків, представлених у вигляді нечітких чисел.

Ключові слова: морські перевезення нечіткі множини, оптимізачія, оперування флотом, фрахтові контракти.
УДК 656.611:258.155

JEL C60 M11

DOI 10.31375/2226-1915-2019-4-15-25

О.Д. Вишневская

к.т.н., доцент кафедры «Эксплуатация флота и технологии морских перевозок»

Д.О. Вишневский

к.т.н., доцент кафедры «Эксплуатация флота и технологии морских перевозок»

С.П. Онищенко

д.э.н., профессор кафедры «Эксплуатация флота и технологии морских перевозок»

Одесский национальный морской университет, Украина

\section{МОДЕЛИРОВАНИЕ РАСПРЕДЕЛЕНИЯ БЮДЖЕТА ВРЕМЕНИ СУДОВ ПО ДОЛГОСРОЧНЫМ ФРАХТОВЫМ КОНТРАКТАМ В УСЛОВИЯХ НЕОПРЕДЕЛЕННОСТИ}

Аннотация. Разработана модель распределения бюджета времени судов по долгосрочным контрактам в условиях нечеткой неопределенности с учетом того факта, что в «свободное» от рабочего времени время по этим контрактам суда могут работать на открытом фрахтовом рынке. Нечеткая неопределенность проявляется в том, что параметры транспортного прочесса, технические и эксплуатационные показатели работы судов и объемы транспортных работ представлены в виде максимального, минимального и наиболее ожидаемого значений, что соответствует реальной ситуации в судоходстве. Предложенная модель позволяет определить: количество судов определенного типа, которое необходимо взять в тайм-чартерную аренду для достижения конкретных иелей при заданных условиях; распределение собственных и арендованных судов компании по долгосрочным контрактам $u$, соответственно, выбор контрактов (в результате оптимизачии отдельные контракты могут быть определены как неэффективные); определение сроков и бюджета времени судов (собственных и арендованных), в рамках которых они будут осуществлять перевозки по этим контрактам, а также доли бюджета времени, в пределах которых они будут работать на свободном фрахтовом рынке. Установленные значения переменных обеспечивают максимизацию операционной прибыли, с учетом ее минимально допустимой границы. Практическое использование модели позволяет судовладельияам планировать работу судов $u$ оченивать результаты их работы при отсутствии полной информации, основанной на прогнозах аналитиков, представленных в виде нечетких чисел.

Ключевые слова: морские перевозки, нечеткие множества, оптимизачия, оперирование флотом, фрахтовые контракть 
Introduction. Shipping is a type of activity that is characterized by a high level of commercial risks connected with the uncertainty of the freight market conditions on the one hand, and the uncertainty of parameters reflecting the production process of vessels, that is, the parameters of the voyage, on the other.

While making a decision about commercial operation of vessels, the shipowner must take into account these commercial risks, regardless of the level of decisions made - operational, medium-term or strategic.

Long-term freight contracts (Contracts of Affreightment) are a form of vessel operation. In [1] it is indicated that long-term freight contracts have certain specific features, including, in most cases, the absence of a clear indication of ports of call and the volume of cargo traffic. Also, during fulfillment of obligations to cargo owners under these contracts, it may be necessary to attract vessels on a time charter basis in a situation when their own vessels are engaged in the carriage of cargoes on the free freight market.

Thus, the shipowner must compare the performance of the vessels on long-term freight contracts and on the open freight market, provided that a mixed version of the vessels operation is possible - partly on obligations under long-term contracts, partly - on the open freight market. At the same time, the terms of contracts, including the volume of transported goods, must be fulfilled.

During evaluation of the effectiveness, the shipowner should take into account the uncertainty of the working conditions of the vessels, regardless of the form of their work - on the open freight market or within long-term freight contracts.

The main factor contributing to the uncertainty of conditions during estimation of the performance of vessels' work in the open freight market is the level of freight rates (whose volatility is known to be quite high) and the volume of demand. The main factors contributing to the uncertainty of conditions during estimation of the performance of vessels' work under long-term freight contracts are the volume of transport work (can be set as an interval according to $[1 ; 2])$ and production parameters, which are difficult to estimate with a high degree of certainty due to the uncertainty of ports of call in the majority of such contracts (according to $[3 ; 4]$ ).

Literature review and problem statement. Uncertainty of freight market has been considered at many papers (for examples [5-11]). A significant part of publications devoted to modeling of the distribution of the vessels' time budget is connected with the distribution on schemes or linear services. At the same time, the practical majority of existing models are based on a deterministic version of setting of vessels' working conditions, since they were developed [1]: 1) during the period of a planned economy (domestic scientific school); 2) for the situation of linear shipping with a focus on a clearly defined set of ports of call, a specific sche-dule and an average variant of vessels' loading capacity.

The uncertainty of the conditions in which certain processes are carried out may be described in various ways depending on the available information. In problems of allocation character with a horizon of a considered period of time of about a year, there are 
three possible approaches to the mathematical description of uncertainty:

- Probabilistic - in this situation, the types and parameters of the laws of allocation of random values, reflecting the indicators and parameters of conditions, must be known;

- Interval - in this situation, the law of allocation is unknown, but the minimum and maximum of the possible values of indicators and parameters of conditions can be estimated (for example, by an expert method);

- Fuzzy - a variant in which the previous situation occurs, but it is possible to evaluate not only the minimum and maximum values, but also to describe the behavior of intermediate values in the form of membership functions.

Probabilistic models for solving problems related to the allocation of vessels are usually used for long-term (more than one year) planning. In particular, in [9] the problem of allocation of vessels between working regions and between two variants of commercial operation options (voyage charter and time charter) was considered, taking into account the probabilistic nature of freight rates (the results of statistical studies that justified the use of the normal freight rates were used as a base).

It should be noted that the information available to the shipowner does not always allow the use of mathematical statistics methods for the further use of probabilistic methods. Thus, the practical use of probabilistic approaches for accounting of uncertainty is rather difficult in the most cases.

In [1], was proposed a model for allocation of vessels' time budget between long-term contracts and work in the open freight market. In order to take into account the uncertainty of the working conditions of vessels, an interval description of the relevant parameters and indicators was used.

However, with the possibility of operating with a large amount of information and, in particular, the possibility of estimating not only the maximum and minimum, but also the most expected value of a parameter or indicator, fuzzy sets theory can be used, which, unlike the interval description of uncertainty, will give more reasonable result, taking into account the operation of more structured information.

Thus, this research relies on a substantive level on the results presented in [1]. As a theoretical basis of using the theory of fuzzy sets in modeling problems of resource allocation, were used the results presented in $[10 ; 11]$.

The aim of the study. The aim of this study is a development and practical testing of a model for allocation of vessels' time budget under long-term freight contracts, taking into account the uncertainty of their working conditions, described in terms of fuzzy sets.

Results of modeling. The structure of the proposed model reflects the purpose and basic limitations connected with the results of vessels' work for specific company question during planned period.

The main purpose of the allocation of vessels by type of work in the considered time period is to maximize profits, the structure of which should include:

- revenues from two types of vessels operations - on long-term freight contracts and on the open freight market;

- operating costs; 
- the cost of renting vessels for the case of using time-charter vessels.

The limitations of the model reflect next conditions:

- in transportation volumes under long-term freight contracts;

- in traffic volumes on the open freight market (in a given region);

rented vessels;

- on time budget of own and

- by the number of leased vessels.

At the same time, it is assumed that in the open freight market there is no allocation of vessels for specific destinations and the vessels operate according to the classical tramp scheme. Therefore, during the estimation of the performance of vessels' work in the open freight market, the averaged (for the region and for a given type of vessels) time-charter equivalent is taken as the base, and not the freight rates. The structure of the averaged time-charter equivalent takes into account [12] freight rates for the transportation routes within the region, operating costs, and the duration of voyages for the possible directions of transportation.

The assumption of the model is to consider only one region for the operation of vessels. A natural development of the model can be the consideration of the set of geographic regions of the freight market.

As it was determined above, the uncertainty of the conditions and results of the vessels' work is given in the form of fuzzy sets. Following the results of [11-14], the most practical option is to use fuzzy triangular numbers for specified purposes - specific fuzzy sets whose structure corresponds to a threelevel estimation of the values of parameters and indicators - maximum, mini- mum, and the most expected ones. Triangular fuzzy numbers have the form $\tilde{A}=\left\langle a_{1}, a_{2}, a_{3}\right\rangle$, and their membership function has the form

$$
\mu_{\tilde{A}}(x)=\left\{\begin{array}{l}
\frac{x-a_{1}}{a_{2}-a_{1}}, x \in\left[a_{1}, a_{2}\right], \\
\frac{x-a_{3}}{a_{2}-a_{3}}, x \in\left[a_{2}, a_{3}\right], \\
0, x \notin\left[a_{1}, a_{2}\right] \cup\left[a_{2}, a_{3}\right] .
\end{array}\right.
$$

At the same time the condition $a_{1} \leq a_{2} \leq a_{3}$ is fulfilled.

Let's introduce the indications: $i=\overline{1, m}-$ indices of vessels of the company.

The work of each vessel is characterized by

$$
\tilde{R}_{i}=\left\langle r_{i 1}, r_{i 2}, r_{i 3}\right\rangle-\text { the daily }
$$

rate of constant costs, dollars/day;

$$
\widetilde{T C E}_{i}=\left\langle\widetilde{T C E}_{i 1}, \widetilde{T C E}_{i 2}, \widetilde{T C E}_{i 3}\right\rangle-
$$

time-charter equivalent (during the work in the open freight market), dollars/day.

We also take into account the fact that in order to implement its plans for fulfillment of long-term freight contracts or working in the open freight market, a company can replenish its fleet based on the basis of time charter leases at rates $r_{k}^{t-c h}, k=\overline{1, K}$, where $k$ - is a vessel (prototype), $K-$ is a set of considered variants of vessels. At the same time, the work of rented vessels is characterized by the value of the timecharter equivalent

$$
\widetilde{T C E}_{k}=\left\langle\widetilde{T C E}_{k 1}, \widetilde{T C E}_{k 2}, \widetilde{T C E}_{k 3}\right\rangle
$$


$I_{s}-$ coefficient that corrects considered period of time $\mathrm{T}$, taking into account commercially unused time, that is, the time when vessels do not perform transportation (for example, unscheduled repairs, bad weather, etc.).

At the same time, condition $0<I_{s}<1$ is also fulfilled.

Let's set $j=\overline{1, n}$ as indices of considered long-term freight contracts. Considered period of long-term contracts is $\mathrm{T}$, days.

Each contract is characterized by $\tilde{Q}^{j}=\left\langle Q_{1}^{j}, Q_{2}^{j}, Q_{3}^{j},\right\rangle$ - traffic volume, $\mathrm{t}$;

$f_{j}-$ the value of the freight rate, dollars/t.

The work of the company's vessels under contracts is characterized by the following technical and operational indicators

$$
\tilde{r}_{i j}=\left\langle r_{i 1}^{j}, r_{i 2}^{j}, r_{i 3}^{j},\right\rangle \text { - operating }
$$

costs during the operation of the i-th vessel under the $j$-th contract, dollars/day;

$$
\tilde{p}_{i j}=\left\langle p_{i 1}^{j}, p_{i 2}^{j}, p_{i 3}^{j},\right\rangle-\text { carrying }
$$

capacity of the $i$-th vessel during the operation under the $\mathrm{j}$-th contract, thousand tons/year;

$$
\tilde{p}_{i}=\left\langle p_{i 1}, p_{i 2}, p_{i 3},\right\rangle-\text { carrying }
$$

capacity of the $i$-th vessel during the operation in the considered region, thousand tons/year.

The work of rented vessels under long-term freight contracts is characterized by the following indicators:

$$
\tilde{r}_{k j}=\left\langle r_{k 1}^{j}, r_{k 2}^{j}, r_{k 3}^{j},\right\rangle \text {-operating }
$$

costs during the operation of the $i$-th vessel under the $j$-th contract, dollars/day;

$$
\tilde{p}_{k j}=\left\langle p_{k 1}^{j}, p_{k 2}^{j}, p_{k 3}^{j},\right\rangle \text { - carrying }
$$

capacity of the $i$-th vessel during the operation under the $j$-th contract, thousand tons/year;

$$
\tilde{p}_{k}=\left\langle p_{k 1}, p_{k 2}, p_{k 3},\right\rangle-\text { carrying }
$$

capacity of the $i$-th vessel during the operation under the $j$-th contract, thousand tons / year.

Let's introduce model variables:

$$
x_{i j}, 0 \leq x_{i j} \leq 1 \text { - the share of }
$$

the time budget of the $i$-vessel under the $j$-th contract. Since not every vessel from the considered set can work under specific contract (for example, a cargo consignment does not fit in size for a given vessel), in such a situation, some $x_{i j}$ of the control parameters are taken exogenously as 0 . This procedure will exclude from the further optimization «impossible» options for allocation of vessels under contracts [1];

$$
x_{k}^{\text {tch }}, k=\overline{1, K} \text { - the number of }
$$

vessels of type $\mathrm{k}$ leased under time charter;

$$
x_{k j}^{t c h}, k=\overline{1, K}, j=\overline{1, n}-\text { the }
$$

share of the time budget of the $k$-th vessel under the $j$-th contract. Similarly to the arguments presented above, if a vessel $x_{k}^{\text {tch }}$ cannot serve under the $j$-th cont-ract, then the corresponding $x_{k j}^{t c h}$ are set to 0 and are considered further as exogenous parameters.

According to the given designation of variables 


$$
1-\sum_{j=1}^{n} x_{i j}, i=\overline{1, m}-\text { the share of }
$$

the time budget of the $\mathrm{i}$-th vessel in the open freight market;

$$
1-\sum_{j=1}^{n} x_{k j}^{\text {tch }}, k=\overline{1, K} \text { - the share of the }
$$

time budget of the $k$-th vessel leased under time-charter on an open freight market;

$$
x_{k}^{t c h}-\sum_{j=1}^{n} x_{k j}^{t c h}-\text { the share of the }
$$

time budget of leased vessels out of

$$
\begin{aligned}
& \widetilde{\operatorname{Pr}}=\sum_{j=1}^{n}\left(f^{j} \cdot\left(\sum_{i=1}^{m} \tilde{p}_{i j} \cdot x_{i j}+\sum_{k=1}^{K} \tilde{p}_{k j} \cdot x_{k j}^{t c h}\right)-\sum_{i=1}^{m}\left(\tilde{r}_{i j} \cdot x_{i j}-\tilde{R}_{i j}\right)-\right. \\
& \left.-\sum_{k=1}^{K} \tilde{r}_{k j} \cdot x_{k j}^{x c h}\right)-\sum_{k=1}^{K} T \cdot r_{k} \cdot x_{k}^{t c h}+ \\
& +\sum_{i=1}^{m} I_{s} \cdot T \cdot \widetilde{\operatorname{TCE}_{i}} \cdot\left(1-\sum_{j=1}^{n} x_{i j}\right)+
\end{aligned}
$$

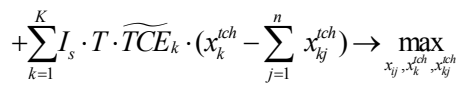

Considering the fuzzy nature of the indicators in (2) used as coefficients, the total profit value is also a fuzzy number $\widetilde{\mathrm{Pr}}$.

Structure (2) corresponds to the structure of profits from the work of own and leased vessels under long-term contracts and in the open freight market

$$
\sum_{j=1}^{n}\left(\sum_{i=1}^{m} \tilde{p}_{i j} \cdot x_{i j}+\sum_{k=1}^{K} \tilde{p}_{l j} \cdot x_{l j}^{t c h}\right)-
$$

amount of cargo transported under all long-term contracts by all vessels (own and leased);

$$
\sum_{j=1}^{n}\left(f^{j} \cdot\left(\sum_{i=1}^{m} \tilde{p}_{i j} \cdot x_{i j}+\sum_{k=1}^{K} \tilde{p}_{k j} \cdot x_{k j}^{k c h}\right)-\right.
$$

amount of freight from the work of vessels (own and leased) under contracts;

$$
\sum_{i=1}^{m}\left(\tilde{r}_{i j} \cdot x_{i j}-\tilde{R}_{i}\right) \quad-\quad \text { operating }
$$

expenses and fixed costs of the company's own vessels; long-term contracts - in the

According to the model structure presented above, as an objective function reflecting the main goal of the company, we will use the maximization of profit from the work of vessels (own and leased) under long-term contracts and in the open freight market:

$$
\sum_{k=1}^{K} r_{k j} \cdot x_{k j}^{t c h}-\text { operating costs of }
$$

leased vessels;

$$
\sum_{k-1}^{K} K \cdot r_{k} \cdot x_{k}^{t c h}-\text { costs of leased }
$$

vessels under time-charter;

$\sum_{i=1}^{m} I_{s} \cdot T \cdot \widetilde{T C E_{i}} \cdot\left(1-\sum_{j=1}^{n} x_{i j}\right)-\quad$ profit

excluding fixed costs from the work of own vessels outside long-term contracts - in the open freight market;

$$
1-\sum_{j=1}^{n} x_{i j} \text { - the share of the time }
$$

budget of own vessels outside long-term contracts

$$
\sum_{k=1}^{K} I_{s} \cdot T \cdot \widetilde{T C E}_{k} \cdot\left(x_{k}^{\text {tch }}-\sum_{j=1}^{n} x_{k j}^{\text {tch }}\right)-\text { profit }
$$

excluding fixed costs from the operation of rented vessels in the open freight market.

The limitations of the model correspond to the listed above conditions 
for contracts, vessels and the freight market:

in volume of transport work for each contract

in of the volume of transport work in the free freight market (in a given geographical region)

$\sum_{i=1}^{m} \tilde{p}_{i} \cdot\left(1-\sum_{j=1}^{n} x_{i j}\right)+\sum_{k=1}^{K} \tilde{p}_{k} \cdot\left(1-\sum_{j=1}^{n} x_{k j}^{\text {ch }}\right) \subseteq \tilde{Q} ;$

in the time budget of the company's own vessels

$$
\sum_{j=1}^{n} x_{i j} \leq 1, i=\overline{1, m}
$$

in time budget of leased vessels

$$
\sum_{j=1}^{n} x_{k j}^{t c h} \leq x_{k}^{t c h}, k=\overline{1, K} \text {; }
$$

in the number of leased vessels

$$
x_{k}^{\text {tch }} \leq N_{k}, k=\overline{1, K} \text {. }
$$

$N_{k}$ - the possible number of vessels for rent.

Restrictions in the possible values of the time budget allocation of own vessels

$$
0 \leq x_{i j} \leq 1, i=\overline{1, m}, j=\overline{1, n} \text {. }
$$

$$
\begin{aligned}
& \sum_{j=1}^{n}\left(f^{j} \cdot\left(\sum_{i=1}^{m} \tilde{p}_{i j} \cdot x_{i j}+\sum_{k=1}^{K} \tilde{p}_{k j} \cdot x_{k j}^{t c h}\right)-\sum_{i=1}^{m}\left(\tilde{r}_{i j} \cdot x_{i j}-\tilde{R}_{i}\right)-\right. \\
& \left.-\sum_{k=1}^{K} \tilde{r}_{k j} \cdot x_{k j}^{t c h}\right)-\sum_{k=1}^{K} T \cdot r_{k} \cdot x_{k}^{t c h}+\sum_{i=1}^{m} I_{s} \cdot T \cdot \widetilde{T C E_{i}} \cdot\left(1-\sum_{j=1}^{n} x_{i j}\right)+ \\
& +\sum_{k=1}^{K} I_{s} \cdot T \cdot \widetilde{T C E_{k}} \cdot\left(x_{k}^{t c h}-\sum_{j=1}^{n} x_{k j}^{t c h}\right) \supseteq \widetilde{\operatorname{Pr}^{*}}
\end{aligned}
$$

It should be noted that during the formulating of model restrictions, those restrictions in which fuzzy numbers ((3), (4), (11)) are to be compared, are written with the consideration of the rules of the fuzzy sets theory using appropriate signs.

The proposed model (2)-(11) allows to define:

$$
\sum_{i=1}^{m} \tilde{p}_{i j} \cdot x_{i j}+\sum_{k=1}^{K} \tilde{p}_{k j} \cdot x_{k j}^{c h} \subseteq \tilde{Q}^{j}, j=\overline{1, n}
$$

The condition of integer and non-negativity of the variables corresponding to the vessels leased under the time charter

$$
x_{k}^{t c h} \in Z^{+}, k=\overline{1, K} \text {. }
$$

The condition of non-negativity of variables that corresponding to the allocation of the time budget of leased vessels

$$
x_{k j}^{t c h} \geq 0, k=\overline{1, K}, j=\overline{1, n} .
$$

It should be noted that the maximization of profits does not mean the achievement of economic goals. Therefore, a set of conditions and corresponding restrictions must be supplemented with a limitation on the lower boundary of the economic efficiency of vessels, for example, on the lower margin of profit $\widetilde{\operatorname{Pr}^{*}}$ 
may be identified as not effective for the company;

3) determination of the time budget shares of vessels (own and leased), within which they will carry out transportation under these contracts, as well as time budget shares, within which they will work on the free freight market. At the same time, established values of the variables ensure the maximiza-tion of operating profit, with the consi-deration of it's minimum permissible boundary.

The results obtained from the model take into account the uncertainty of the conditions formulated in the form of fuzzy numbers, describing the values of technical and operational indicators, as well as the characteristics of long-term contracts and the situations on the freight market. To carry out calculations within proposed model, it is pos-sible to use the methods that are described in detail in [15].

In particular, one of such approaches involves a sequence of the following steps:

1) the introduction of discrete $\alpha$-levels

(usually $\alpha \in\{0,2 ; 0,4 ; 0,6 ; 0,8 ; 1\}$ );

2) transformation of the objective function and constraints to a clear view, taking into account the relevant rules and obtaining of optimization models with clear parameters, the number of models corresponds to the number of $\alpha$-levels;

3) obtaining optimal solutions for each model of $\alpha$ - level and their transformation into a deterministic solution on the basis of the defazzing procedure.

This method is tested in solving of practical problems and allows to obtain the required solution by using of standard applications for solving of optimization problems.

Conclusion. This research presents a model that allows, under conditions of uncertainty characterized by fuzzy sets, to allocate company's own vessels and leased vessels under longterm freight contracts, taking into account the fact that during their free time under these contracts, vessels can operate on the open freight market.

Technical and operational performance of the vessels and the characteristics of contracts and indicators characterizing the situation on the freight market are presented in the form of fuzzy numbers of a triangular type, which reflects the practical availability of information (minimum, maximum, and most possible).

Practical use of the model allows shipowners to plan the work of vessels and evaluate the results of their work in the absence of complete information, based on analysts' forecasts, presented in the form of fuzzy numbers.

\section{СПИСОК ЛІТЕРАТУРИ}

1. Вишневская О.Д. Модель распределения бюджета времени судов по долгосрочнымм фрахтовым контрактам в условиях интервальной неопределенности параметров транспортного прочесса // Вісник ОНМУ. № 53. 2017. С. 184-193.

2. Онищченко С.П., Вишневская О.Д. Метод оиченки отклонений результатов выполнения судном рейса под влиянием факторов риска // Вісник Національного технічного університету «ХПI». Серія: Механіко-технологічні системи та комплекси. 2016. № 7. С. 25-32. 
3. Gorton L. Volume Contracts of Affreightment - Some Features and Principles. Stockholm Institute for Scandianvian Law, (2010), 91 p., available online: URL: http://www.scandinavianlaw.se/pdf/46-3.pdf

4. Implied obligations in a contract of affreightment.URL: https://catalogue. pearsoned. co.uk/assets/hip/gb/hip_gb_pearsonhighered/samplechapter/Wilson_COGBS_C02. $p d f$

5. Albertinj S., Bessler, W. and Drobetz, W. Financing Shipping Companies and Shipping Operations: A Risk-Management perspective. Journal of Applied Corporate Finance, No.23(4), (2011), pp.70-82.

6. Andrews J.D., Moss T.R. Reliability and Risk Assessment. London and Bury St Edmunds, Professional Engineering Publishing, (2002), 540 p.

7. Kavussanos, M.G., Alizadeh, A.H. The expectations hypothesis of the term structure and risk-premia in dry-bulk shipping freight markets, Journal of Transport Economics and Policy, No.36(2), (2002), pp. 267-304.

8. Notteboom, T., Lam, J. Dealing with uncertainty and volatility in shipping and ports, Maritime Policy \& Management, No.41 (7), (2014), pp. 611-614.

9. Онищенко С.П., Шутенко Т.Н. Специфика рыночных рисков и мероприятий по их снижению в современном судоходном бизнесе // Актуальні проблеми економіки. № 2 (128). 2012. C. 85-98.

10. Zadeh, L.A. Fuzzy sets as a basis for a theory of possibility. Fuzzy Sets and Systems, No.1, (1972), pp. 3-28.

11. Leontieva A., Onyshchenko S. Modeling of the optimal composition of the enterprise technical development program, Technology audit and production reserves, Vo. 5, No. 2(43), (2018), pp. 36-41, https://doi.org/10.15587/2312-8372.2018.146463

12. Chuang T.-N., Lin, C.-T., Kung, J.-Y., \& Lin, M.-D. (2010). Planning the route of container ships: A fuzzy genetic approach. Expert Systems with Applications, 37(4), 2948-2956.

13. Notteboom, T., Lam, J. (2014). Dealing with uncertainty and volatility in shipping and ports. Maritime Policy \& Management, 41 (7), 611-614.

14. Lapkin A.I., Lapkina I.A. Efficiency of chartering a vessel under the conditions of a temporary time charter, Bulletin of East Ukrainian National National University, No. 4, Vol. 234, (2017), pp.134-137.

15. Артемов М.А., Матвеев М.Г., Стародубиев И.Ю. Исследование задачи линейного программирования с нечеткими параметрами // Вестник ВГТУ. 2011. Bыnуск № 12-1. C. 39-42.

\section{REFERENCES}

1. Vyshnevska, O. D. Model of the distribution of the budget of the time of the courts for long-term freight contracts in the conditions of interval uncertainty of the parameters of the transport process. OSMU Bulletin, Vol. 53,(2017), pp. 184-193 [In Russian].

2. Onyshchenko, S. \& Vyshnevska, O. (2016). Assessment method for deviation of the work's results for vessel under the influence of risk factors. Bulletin of NTU «KhPI». Series: Mechanical-technological systems and complexes. Kharkov: NTU «KhPI», No. 7 (1179), pp. 25-32. [In Russian].

3. Lars Gorton (2010). Volume Contracts of Affreightment - Some Features and Principles. Stockholm Institute for Scandianvian Law, 91 p., available online: URL: http://www.scandinavianlaw.se/pdf/46-3.pdf 
4. Implied obligations in a contract of affreightment. URL: https:// catalogue pearsoned.co.uk/assets/hip/gb/hip_gb_pearsonhighered/samplechapter/Wilson_COG BS_C02.pdf

5. Albertinj S., Bessler, W. \& Drobetz, W. (2011). Financing Shipping Companies and Shipping Operations: A Risk-Management perspective. Journal of Applied Corporate Finance, No.23(4), pp. 70-82.

6. Andrews, J. D. \& Moss, T.R. (2002). Reliability and Risk Assessment. London and Bury St Edmunds, Professional Engineering Publishing, 540 p.

7. Kavussanos, M.G. \& Alizadeh, A.H. (2002). The expectations hypothesis of the term structure and risk-premia in dry-bulk shipping freight markets, Journal of Transport Economics and Policy, No.36(2), pp. 267-304.

8. Notteboom, T. \& Lam, J. (2014). Dealing with uncertainty and volatility in shipping and ports, Maritime Policy \& Management, No.41 (7), pp.611-614.

9. Onyshchenko S.P. \& Shutenko T.M. (2012). The specifics of market risks and measures to reduce them in the modern shipping business, Actual problems of Economics, No. 2, Vo. 128, pp. 85-98 [In Russian].

10. Zadeh, L.A. (1972). Fuzzy sets as a basis for a theory of possibility. Fuzzy Sets and Systems, No.1, pp. 3-28.

11. Leontieva, A. \& Onyshchenko, S. (2018). Modeling of the optimal composition of the enterprise technical development program, Technology audit and production reserves, Vo. 5, No. 2(43), pp. 36-41. URL: https://doi.org/10.15587/23128372.2018 .146463

12. Chuang T.-N., Lin, C.-T., Kung, J.-Y., \& Lin, M.-D. (2010). Planning the route of container ships: A fuzzy genetic approach. Expert Systems with Applications, 37(4), 2948-2956.

13. Notteboom, T. \& Lam, J. (2014). Dealing with uncertainty and volatility in shipping and ports. Maritime Policy \& Management, 41 (7), 611-614.

14. Lapkin, A.I. \& Lapkina, I.A. Efficiency of chartering a vessel under the conditions of a temporary time charter, Bulletin of East Ukrainian National National University, No. 4, Vol. 234, (2017), pp.134-137.

15. Artyomov, M.A., Matveev, M.G. \& Starodubtsev, I.Yu. (2011). The study of linear programming problems with fuzzy parameters, Bulletin of the Voronezh State Technical University, No.7 (12-1), pp. 39-42 [In Russian].

Стаття надійила до редакиії 16.11.2019

Посилання на статтю: Vyshnevska, O.D., Vyshnevskyi D.O., Onyshchenko S.P. Modeling of the distribution of the vessels' time budget under long-term freight contracts within conditions of uncertainty // Розвиток методів управління та господарювання на транспорті: 3б. наук. праць. 2019. № 4(69). C. 15-25. DOI 10.31375/2226-1915-2019-4-15-25.

Article received 17.10.2019

Reference a JournalArtic: Vyshnevska, O., Vyshnevskyi D. \& Onyshchenko, S. (2019). Modeling of the distribution of the vessels' time budget under long-term freight contracts within conditions of uncertainty Development of management and entrepreneurship methods on transport. DOI 10.31375/2226-1915-2019-4-15-25. 